\title{
SOME BIOCHEMICAL ASPECTS \\ OF THE LEPROMIN REACTION PATTERN EVOKED BY NORMAL LIVER PREPARATIONS
}

\author{
By F. W. K. Grotepass, D.PHIL., and D. H. DE Kock, ${ }^{*}$ M.SC. \\ Department of Biochemistry, University of Pretoria, Pretoria, \\ South Africa \\ and \\ R. Koolst, M.D. \\ Westfort Institution, Union Health Department, Pretoria, \\ South Africa
}

\section{Introduction}

Many attempts have bcen made to develop a diagnostic skin reaction for leprosy, analogous to the tuberculin reaction for tuberculosis. Although not suitable for diagnostic purposes, the reaction described by Mitsuida $(1919,1953)$ is now universally used for the classification of leprosy. Mitsuda used antigens prepared from leproma's, now called "Lepromin". He observed the reactions during the first few days and subsequent weeks and thus found the marked difference of results in lepromatous and in tuberculoid cases of leprosy. Since the reaction is often found to be positive in healthy people, no absolute value for the diagnosis of leprosy could be ascribed to the test.

The above-mentioned late reaction is called the "Mitsuda reaction" and has found world-wide application. Its maximal intensity is usually reached between the third and fourth week after injection. Apart from the late reaction an earlier reaction can be observed between 48 and 72 hours. At first this reaction was regarded as non-specific, but FERNANDEZ (1940) stated that this early reaction ("Fernandez reaction") coincides in its results with the late reaction in the majority of cases.

As lepromin is composed of dead leprosy bacilli and human tissue from the host it is of the utmost importance to know which role is played by the bacilli and (or) the tissue elements in the lepromin reaction. A few workers have attempted to isolate the antigenic fraction of fractions from lepromin. Rabello, ThiERS AND VillelA (1938) reported the isolation from lepromatous tissue of an active non-lipid substance, probably of protein nature. DHARMENDRA (1948) expressed his doubts as to whether the above antigenic

\section{Present Addresses}

* Dept. of Chemistry, University of Stellenbosch, Stellenbosch, South Africa.

† Dept. of Dermatology, Groote Schuur Hospital, Cape Town, South Africa. 
fraction contains protein of the bacilli. PARAS (1943) isolated the major lipid components of lepromatous nodules and HENDERSON (1940) isolated proteins from lepromatous spleen. Tests were carried out with these preparations and only weak Fernandez reactions were seen.

DHARMENDRA (1948) reported a detailed study on this subject. He isolated various chemical fractions and tested the protein, polysaccharide, glyceride, phosphatide and wax substances. He concluded:

(1) That in the lepromatous nodule, only the bacillary matter is antigenic.

(2) The bacilli produce both the Fernandez and Mitsuda reactions.

(3) The lipids from the nodule showed slight activity, but this is believed to be caused by traces of bacillary matter.

(4) The nodular tissue freed from bacilli is not antigenically active.

(5) Of all the fractions isolated from the bacilli, only the protein fraction is positive, producing only the Fernandez reaction.

Other workers have postulated the existence of two different substances, one for the Fernandez and the other for the Mitsuda reaction. From the above it is clear that the findings of the various investigators are very contradictory.

KoOIJ AND GERrITSEN $(1956,1958)$ showed that positive leprominlike reactions could be evoked with a suspension prepared from normal tissue not containing leprosy bacilli.

In Table A some of their results are shown.

Kooij and Gerritsen who chiefly concerned themselves with the Mitsuda reaction, assume that the presence of particles is essential for this reaction. For further particulars see Kools et al (1956, 1958, 1959). This lepromin-like activity of normal tissue suspensions was recently confirmed by DAVEY AND DREWETT (1958).

One must distinguish between two types of epithelioid cell reactions. The first which gives epithelioid cell reactions in both the lepromatous type and tuberculoid type of leprosy as was shown by Kooij and Pepler (in press) for BCG. The second produces only an epithelioid cell reaction in tuberculoid leprosy and no reaction or only very weak in lepromatous leprosy. The latter we call the lepromin reaction pattern, which can be evoked by lepromin, and by certain suspensions of normal tissue and by Kveim antigen.

\section{Purpose of the Investigation}

The aim of the present investigation was $(a)$ to find the active constituent in normal human liver which produced the lepromin 
TABLE A

Average readings in $\mathrm{mm}$. with various preparations from normal human liver.

TUBERCULOID LEPROSY

$\begin{array}{crrccc}\text { Prep. } & 48 \text { hrs. } & 1 \text { week } & 2 \text { weeks } & \text { 3 weeks } & 4 \text { weeks } \\ \text { N }(19)^{*} & 1.9 & 1.7 & 1.9 & 0.9 & 0.6 \\ \text { O (15) } & 4.3 & 3.0 & 1.9 & 1.7 & 1.6 \\ \text { V (20) } & 3.6 & 7.1 & 7.1 & 5.0 & 3.7 \\ \text { W (15) } & 8.0 & 7.0 & 6.9 & 8.5 & 8.9\end{array}$

\section{LEPROMATOUS LEPROSY}

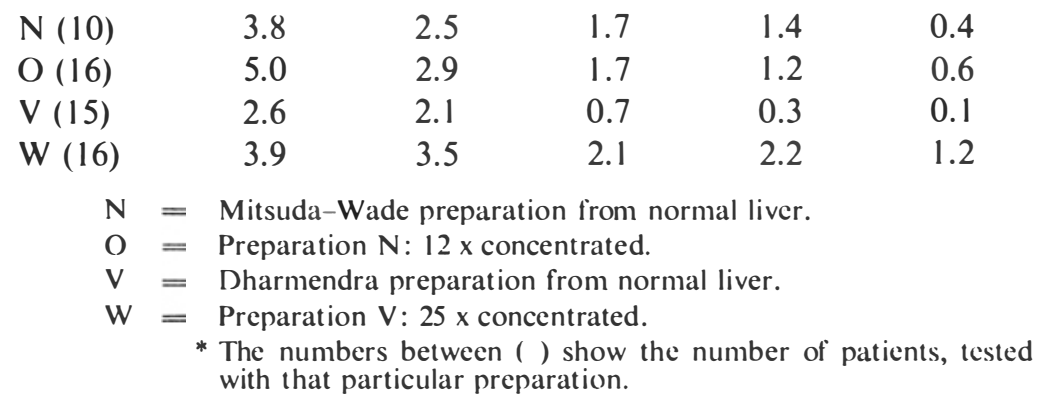

pattern of reaction, (b) to investigate the hypothesis of Kooij and Gerritsen that the presence of particles and their size might be of importance and that in the Mitsuda reaction we are dealing with a kind of foreign body reaction.

The investigations described in this paper were conducted with a suspension prepared from normal human liver in the same manner as lepromin from lepromatous tissue. As Kooij and Gerritsen obtained the strongest reactions with suspensions of normal liver prepared by the Dharmendra method, we also used this method.

\section{Experimental Procedure}

Preparation of normal tissue suspensions: (Dharmendra method).

Normal human liver was autoclaved in a $0.9 \%$ sodium chloride solution at $120^{\circ} \mathrm{C}$. and $15 \mathrm{lbs}$. per sq. inch for 20 minutes.

One hundred grams of the autoclaved liver were thoroughly blended and extracted with $200 \mathrm{ml}$. of chloroform in a Waring blender and filtered through a thick layer of cheese cloth. The residue was subjected to three successive extractions with $200 \mathrm{ml}$. of chloroform and the extracts combined. The chloroform was removed by distillation under reduced pressure and the syrupy residue was extracted with ether to remove the ether soluble lipids. After each extraction the particles were separated by centrifugation for 10 
minutes at 3,000 r.p.m. and finally dried at $40^{\circ} \mathrm{C}$. for a few minutes. It should be noted that after the final washing the ether layer must be colourless and transparent, indicating that all ether soluble lipids have been removed. The average yield of the lepromin thus prepared, was $1.5 \mathrm{gm}$. from $100 \mathrm{gms}$. of liver. The particles were suspended in $0.9 \%$ sodium chloride $0.5 \%$ phenol solution and $0.1 \mathrm{cc}$. was intradermally injected in Bantu patients with tuberculoid and lepromatous leprosy.

Experiment 1: To prepare a suspension which is able to produce satisfactory reactions, various concentrations of the tissue suspensions were made in $10 \mathrm{ml} .0 .9 \%$ sodium chloride $0.5 \%$ phenol solution.

The results of the average readings are shown in Table 1 and Fig. 1 .

\section{TABLE 1}

Average readings in $\mathrm{mm}$. of various concentrations Dharmendra normal tissue suspension.

\begin{tabular}{lrrccc}
\multicolumn{5}{c}{ TuiberCulOID LeProsy } \\
Prep. & 48 hrs. & 1 week & 2 weeks & 3 weeks & 4 weeks \\
A $(15)^{*}$ & 2.4 & - & - & - & .8 \\
B $(15)$ & 3.3 & 3.1 & 2.5 & 2.8 & 2.8 \\
C $(18)$ & 4.4 & 3.5 & - & 3.5 & 3.5 \\
D (15) & 5.2 & 4.3 & 3.9 & 3.9 & 3.9 \\
E (11) & 5.5 & 5.2 & 5.2 & 5.2 & 5.2
\end{tabular}

$\begin{array}{lrrccc}\text { Prep. } & 48 \text { hrs. } & 1 \text { week } & 2 \text { weeks } & 3 \text { weeks } & 4 \text { weeks } \\ \text { A (15) } & .6 & - & - & - & 0 \\ \text { B (15) } & 1.9 & 1.3 & 1.0 & 0.6 & 0.5 \\ \text { C (10) } & 3.9 & 3.0 & - & 2.0 & 1.4 \\ \text { D (15) } & 3.5 & 2.5 & 2.1 & 2.0 & 2.0 \\ \text { E (15) } & 5.2 & 4.4 & 3.3 & 3.2 & 3.2\end{array}$

$$
\begin{aligned}
A= & 100 \mathrm{mg} . / 10 \mathrm{ml} . \\
B= & 200 \mathrm{mg} . / 10 \mathrm{ml} . \\
\mathrm{C}= & 400 \mathrm{mg} / 10 \mathrm{ml} . \\
\mathrm{D}= & 600 \mathrm{mg} . / 10 \mathrm{ml} . \\
\mathrm{E}= & 800 \mathrm{mg} . / 10 \mathrm{ml} . \\
& * \text { See note Table A. }
\end{aligned}
$$

We confine ourselves in this article to the Mitsuda reaction read after 28 days. The results of this experiment show that the reactions produced by preparation A and B were too weak and could thus not be used. Preparations C and D successfully produced positive Mitsuda reactions in tuberculoid leprosy. Preparation D produced too strong a reaction in lepromatous cases and was thus omitted as a suitable suspension. We could not succeed in producing such 


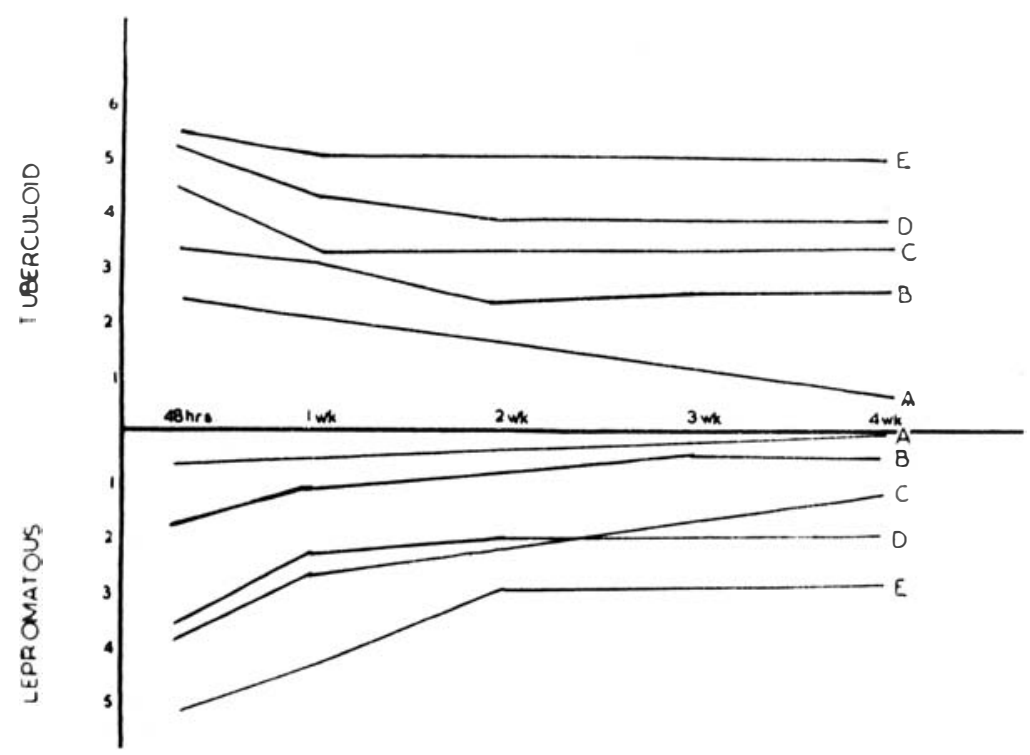

Fig. 1. Average readings in $\mathrm{mm}$. of various concentrations Dharmendra tissue suspension. For explanations see Table 1, Experiment 1.

strong reactions, as was reported by KoOIJ AND GERRITSEN (1958) who used $80 \mathrm{mg}$./10 ml. suspension (Prep. W in the "introduction"). See "Discussion". Preparation C was used by us as the most suitable suspension. Preparation E also evoked too strong reactions in the lepromatous leprosy and these reactions also tended to ulcerate.

Experiment 2: To investigate the influence of the particles and particle size, the following attempts were made to annihilate them.

(a) Four-hundred milligrams Dharmendra tissue suspension in $10 \mathrm{ml}$. of phenol saline solution were irradiated with ultrasonic waves for 20 minutes and then injected as before.

(b) Two-hundred milligrams were hydrolysed for 12 hours with $6 \mathrm{~N} \mathrm{H}_{2} \mathrm{SO}_{4}$ to break up the proteins, polysaccharides etc. in their fundamental compounds and thus removing them. The residue was washed until free from acid, suspended in $5 \mathrm{ml}$. and injected.

(c) A suspension of $200 \mathrm{mg}$. silica (particle size about $5 \mu \mathrm{com}$ pared to the 3-4 $\mu$ of the tissue particle size) in $5 \mathrm{ml}$. saline phenol solution, diluted to facilitate administration, was injected. It should be noted that this was not a colloidal silica preparation as was used by Shelley and Hurley (1960).

(d) The particles were digested by means of the proteolytic enzyme, trypsin. In order to obtain the optimum $\mathrm{pH}$ of 8 for Trypsin action, $200 \mathrm{mg}$. of normal tissue suspension were 
mixed with $2 \mathrm{ml}$. $1 \%$ trypsin and $2 \mathrm{ml}$. of $0.5 \%$ sodium carbonate. One control preparation was also made and the two reaction mixtures incubated for 3 hours at $37^{\circ} \mathrm{C}$. Subsequently, after inactivating the enzyme by heating in a boiling waterbath for 30 minutes, the $\mathrm{pH}$ was adjusted to 7.4. Fig. 2.

The results of the average readings are shown in Table 2 and

TABLE 2

Average readings in $\mathrm{mm}$. of the various preparations tested in Experiment 2.

\begin{tabular}{crcccc} 
Prep. & 48 hrs. & 1 week & 2 weeks & 3 weeks & 4 weeks \\
A (18)* & 3.4 & 3.0 & - & 2.8 & 2.7 \\
B (12) & 4.1 & 4.0 & - & 4.2 & 3.0 \\
C (15) & 1.1 & 0.9 & 0.5 & 0.1 & 0 \\
D (15) & 1.1 & 1.1 & 0.9 & 0.1 & 0.1 \\
E (15) & 1.1 & 1 & 0.6 & 0.1 & 0.1 \\
\multicolumn{5}{c}{} \\
Prep. & 48 hrs. & 1 week & 2 weeks & 3 weeks & 4 weeks \\
A (10) & 3.1 & 1.9 & - & 1.5 & 1.5 \\
B (6) & 1.7 & 1.7 & - & 1.7 & 1.7 \\
C (14) & 0.5 & 0.3 & 0.2 & 0.2 & 0 \\
D (14) & 0 & 0 & 0 & 0 & 0 \\
E (14) & 0 & 0 & 0 & 0 & 0
\end{tabular}

\footnotetext{
$A=400 \mathrm{mg} . / 10 \mathrm{ml}$. Irradiated by ultrasonic waves.

B $=200 \mathrm{mg} . / 5 \mathrm{ml}$. Hydrolysed by $6 \mathrm{~N} \mathrm{H}_{2} \mathrm{SO}_{4}$.

C $=200 \mathrm{mg}$. silica $/ 5 \mathrm{ml}$.

$\mathrm{D}=200 \mathrm{mg}$. in approx. $5 \mathrm{ml}$. solution. Digested by trypsin.

$\mathrm{E}=$ Trypsin control.

* See note Table A.
}

Preparation A, which was irradiated by ultrasonic waves, in an attempt to destroy or break them up in smaller fragments, evoked a slightly weaker reaction than the equivalent, which was not irradiated (See Experiment 1, Prep. C). It was, however, impossible to destroy the particles completely by ultrasonic waves. The residue which contained particles of unknown composition after the hydrolysis with $6 \mathrm{~N} \mathrm{H}_{2} \mathrm{SO}_{4}$ (Preparation $\mathrm{B}$ ) showed positive lepromin-like reactions and it could be concluded that the active principle was not destroyed. As a further method, the particles were treated with the enzyme, trypsin. The results show that the latter preparation, where the proteins of the particles were broken down to their fundamental amino acids and peptides, reacted negative in both the lepromatous and tuberculoid leprosy. It could be assumed that this preparation 


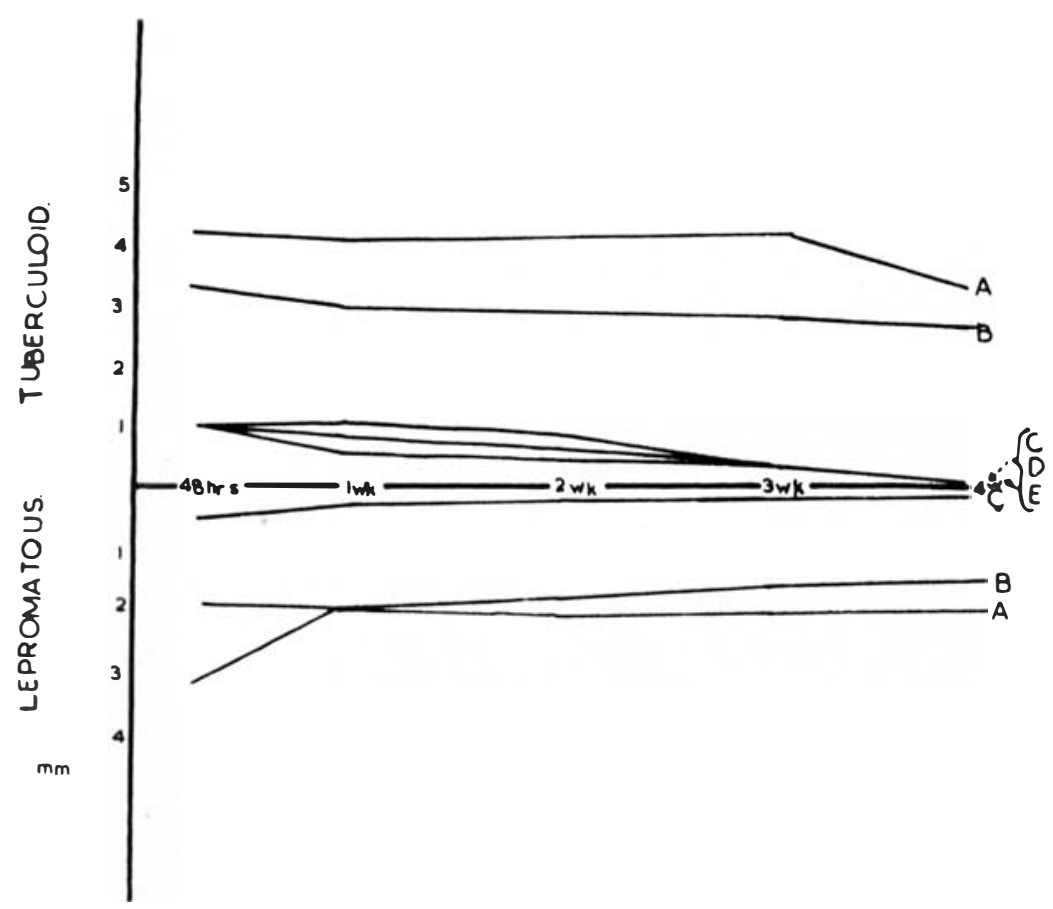

Fig. 2. Average readings in $\mathrm{mm}$. of the various preparations tested in experiment 2. For explanation see Table 2.

did not contain any perceptible macroparticles. It seems also that the proteins are not responsible for this reaction, although it might have some influence. Preparation $\mathrm{C}$ showed only negative results.

The results of this experiment indicate that the presence of tissue particles might be of importance for the lepromin reaction pattern evoked by normal tissue preparations, but also that not every particle does it. (Preparation C).

Experiment 3: In order to investigate the action of the ether insoluble lipids, a chloroform extract of the Dharmendra normal tissue preparations was tested. Four-hundred milligrams were extracted in a micro-soxhlett apparatus with $50 \mathrm{ml}$. of chloroform for 8 hours.

After evaporation of the chloroform under reduced pressure the $25 \mathrm{mg}$. fatty extract was emulsified in $2 \mathrm{ml}$. of phenol saline solution. The residue after chloroform extraction was also suspended in $10 \mathrm{ml}$. of phenol saline solution, and tested.

Chromatographic examination of the lipid fraction was carried out according to AsSELINEAU (1952) and BEVAN et al (1951). As solvent, a chloroform :ethanol:water $(80: 20: 2.5$, by vol.) system was used. Ten microliters of a $1 \%$ solution of the fatty extract was applied on Whatman No. 1 paper and the chromatogram developed for 
6 hours. To locate the position of the lipid, the paper was dried at $100^{\circ} \mathrm{C}$. in an oven and then treated with a $1 \%$ solution of Phosphomolybdic acid in a mixture of equal parts of chloroform and ethanol, and dried again at $100^{\circ} \mathrm{C}$. A yellow spot, $R_{f}$ value 0.9 , was found which corresponds with the sphingomyelin group of the phospholipids. Ninhydrin treatment showed in one chromatogram a very faint purple spot, due to cephalin, but this could not be confirmed by further chromatography.

The average readings in 5 patients with tuberculoid leprosy and 4 patients with lepromatous leprosy injected with the above preparation, as well as the lipid-free preparation, were as follows. See Table 3 and Fig. 3. No histological investigation of the reaction papules was carried out.

TABLE 3

Average readings in $\mathrm{mm}$. of the lipid, lipid-free and control preparations.

\section{TUBERCULOID LEPROSY}

$\begin{array}{crrccc}\text { Prep. } & 48 \text { hrs. } & 1 \text { week } & 2 \text { weeks } & 3 \text { weeks } & 4 \text { weeks } \\ \text { A }(5)^{*} & 6.5 & 5.2 & 5.4 & 5.4 & 5.0 \\ \text { B (15) } & 3.5 & 2.5 & 2.3 & 2.1 & 1.8 \\ \text { C (18) } & 4.4 & 3.5 & - & 3.5 & 3.5\end{array}$

\section{LEPROMATOUS LEPROSY}

$\begin{array}{llllll}\text { A (4) } & 6.0 & 3.0 & 3.0 & 1.0 & 1.0 \\ \text { B (15) } & 3.3 & 1.7 & 1.4 & 0.9 & 0.6 \\ \text { C (10) } & 3.9 & 3.0 & - & 2.0 & 1.4\end{array}$

$A=$ Lipid fraction.

$B=$ Lipid-free fraction.

C $=$ Prep. C: Experiment 1.

* See note Table A.

There seems to be a tendency for this lipid fraction to follow the lepromin pattern of reaction. However, the number of patients tested was small and further investigation was necessary. The absolute lipid-free fraction (B) showed positive results although weaker than the control preparation (Preparation $\mathrm{C}$ ).

The lipid extract of the same concentration as in the earlier experiment was then injected in 15 patients with tuberculoid leprosy, and in 14 patients with lepromatous leprosy. In half of the tuberculoid cases and half of the lepromatous cases the reaction papule was excised 3 weeks after injection and the reaction papules of the remaining patients were excised after 4 weeks and examined histologically.

The average readings are shown in Table 4. 


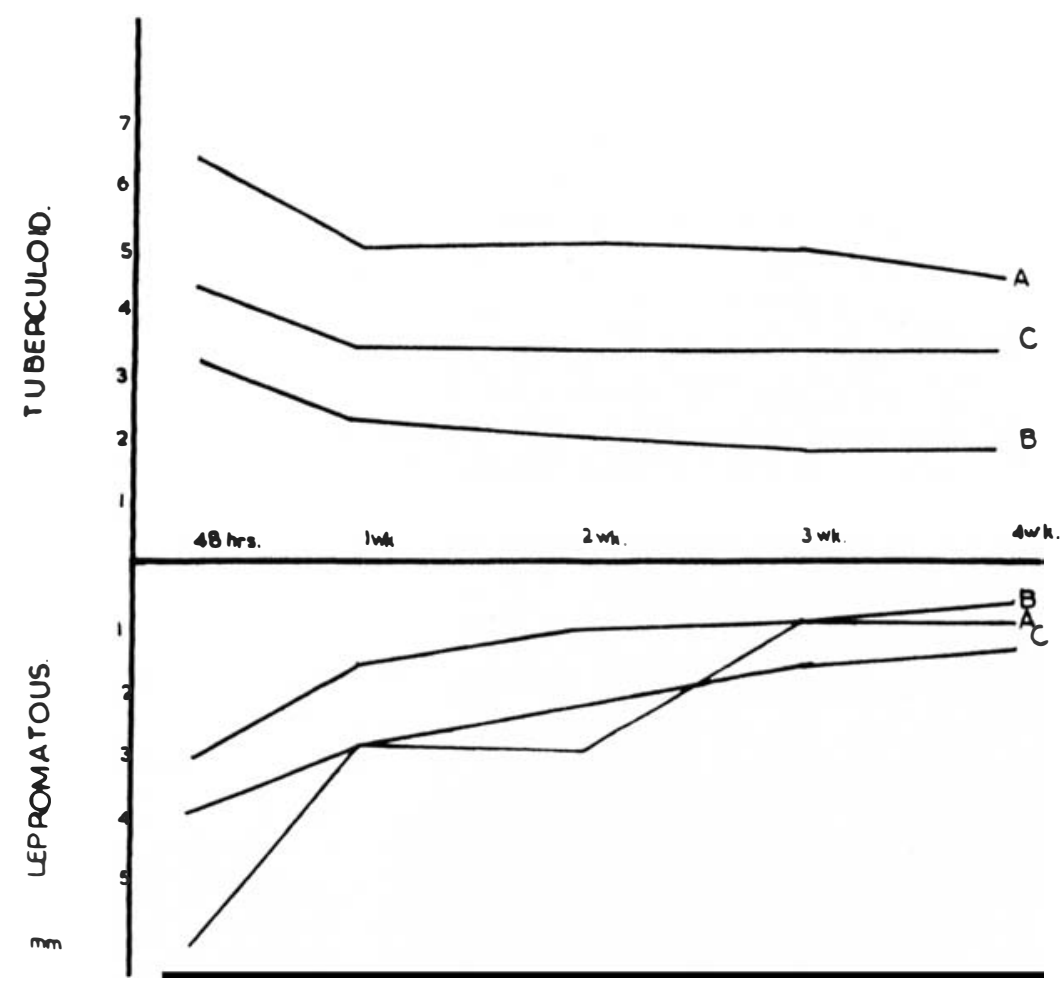

Fig. 3. Average readings in $\mathrm{mm}$. of the lipid, lipid-free and control preparations. For explanation see Table 3.

From these experiments it was evident that the lipid extract produced reactions in both tuberculoid and lepromatous cases, although weaker in the latter type. The absolute lipid-free preparations (Table 3, Prep. B) evoked weaker reactions than the control preparation (Table 3, Prep. C), probably because some active principle was removed.

Although the average readings of the reaction papules in the lepromatous cases after 3 and 4 weeks are somewhat lower than those of tuberculoid cases, the general pattern cannot be called the lepromin pattern of reaction. The readings are therefore too high

\section{TABLE 4}

Average readings in $\mathrm{mm}$. of the lipid fraction.

\begin{tabular}{ccccc}
\multicolumn{5}{c}{ TUBERCULOID } \\
48 hrs. & 1 week & 2 weeks & 3 weeks & 4 weeks \\
6.1 & 5.9 & 5.6 & 5.3 & 4.9 \\
& \multicolumn{5}{c}{ LePromatous } \\
6.0 & 4.2 & 4.3 & 3.7 & 3.1
\end{tabular}


in the lepromatous cases. Histologically the lipid fraction evoked an epithelioid cell reaction in several cases. This was only slight and did not occur in the lepromatous cases. However, compared to an active normal tissue suspension the epithelioid cell reaction was very weak and did not occur in sufficient cases of tuberculoid leprosy.

\section{Discussion}

Although we could confirm the results of KoOIJ ANI) Gerritsen, the reactions obtained with our preparations from normal liver were considerably weaker in evoking the lepromin reaction pattern. Probably the composition of the livers used for the preparation of the tissue suspensions was not the same due to age, unknown diseases, etc. In preparing these tissue suspensions, attention should be given to these conditions.

Irradiation by ultrasonic waves and also breaking down of the proteins and other hydrolysable compounds by $6 \mathrm{~N} \mathrm{H}_{2} \mathrm{SO}_{4}$ did not decrease the activity of the normal tissue preparation much. Both preparations still contained particles. Complete destruction of the particles by the enzyme, trypsin, lead to a preparation which was inactive. The influence of the lipid fraction was probably eliminated by the higher degree of dilution. KoOIJ AND GERritsen (1958) also found that bacterial filtrates of normal liver suspensions were inactive. This indicates that the particles and probably their size are of great importance if not essential for eliciting the lepromin pattern of reaction by a normal tissue suspension. That a special particulate state can be of importance for producing an epithelioid cell reaction was recently shown by Shelley AND Hurley (1960) who demonstrated that epithelioid silica granulomas could be evoked regularly in any individual by intradermal injection of colloidal silica and that the phenomenon is dependent on the colloidal nature of the silica. It is not known yet how colloidal silica reacts in lepromatous leprosy. This problem is under investigation.

In addition, a certain chemical composition of the particles seems essential because not every particle evokes the reaction. The reactions produced by the isolated lipid fraction (Exp. 3, Prep. A) were stronger than those of the control (Exp. 3, Prep. C), however, the readings in lepromatous leprosy were rather high. This does not resemble the lepromin reaction pattern. Histologically, the lipid fraction produced a very weak epithelioid cell reaction in several tuberculoid cases but none in lepromatous cases. On the contrary the lipid free preparation containing particles (Exp. 3, Prep. B) showed weaker reactions than the control, but more the typical lepromin reaction pattern. Unfortunately no histological examination of the reaction papules were carried out. It should be stressed that in future research in this field histological examination is necessary. 
Although the lipid fraction did not elicit the typical lepromin type of reaction it is still of interest that a substance can be isolated from normal liver tissue which produces epithelioid cell reactions. It is possible that this or a similar substance was responsible for the histological sarcoid reaction which SONES et al (1955) obtained with filtrates of a Kveim antigen prepared from sarcoid lymph nodes. If this explanation is correct it does not support the view that the $\mathrm{K}$ viem reaction in sarcoidosis is a response to the introduction of a specific antigen.

As the normal tissue suspension contains both particles and the isolated lipid fraction it is possible that they co-operate in evoking the lepromin pattern of reactions.

\section{Summary}

1. We could confirm the results found by Kooij and Gerritsen, but were unable to produce such strong reactions reported by them. This deflection might probably be due to a difference in age, unknown diseases, etc. of the individual.

2. Annihilation of the particles by ultrasonic waves was unsuccessful. Preparations of normal liver tissue irradiated with ultrasonic waves, as well as an absolute lipid free suspension and the residue after $6 \mathrm{~N} \mathrm{H}_{2} \mathrm{SO}_{4}$ hydrolysis still showed the lepromin pattern of reaction. By means of trypsin an inactive preparation was obtained which failed to produce the lepromin pattern of reaction. Therefore it is assumed that the particulate state is of importance, if not essential.

3. A lipid substance, sphingomyelin, was isolated from normal liver preparations which was able to produce epithelioid cell reactions but not the typical lepromin pattern of reaction. This finding is not in favour of the view that the Kveim antigen contains an antigen specific for sarcoidosis.

4. It is possible that the particles and the isolated lipid fraction co-operate in producing the lepromin pattern of reaction evoked by normal liver suspensions.

\section{Acknowledgement}

We are indebted to Dr. W. J. Pepler, Dept. of Pathology, University of Pretoria, for the histological investigations, Dr. Gerritsen, National Nutrition Research Institute, South African Council for Scientific and Industrial Research, Pretoria, for the preparation of the silica and to Dr. Davison and his staff, Westfort Institute, Pretoria, for their assistance. This paper is published with the permission of the Secretary of Health, Pretoria. 


\section{References}

Assei.ineau, J. (1952) Bull. Soc. Chim. France. 884.

Bevan, T., Gregory, G., Mal.kin, T. and Poole, P. (1951) J. Chem. Soc. 841.

Davey, T. F. and Drewet T, S. E. (1958) Leprosy Rev. 29, 197.

Dharmenidra (1948) Belra Med. Series, $1,1$.

Fernanidez, J. H. M. (1940) Int. Journ. Lep. 8, 1.

Henderson, H. J. (1940) Int. Journ. Lep. 8, 271.

Kools, R. and Gerritsen, Th. (1956) Int. Journ. Le'p. 24, 171.

Koolj, R. and Gerritsen, Th. (1958) Dermatologica 116, 1.

KoolJ, R. and PePler, W. J. and Wainwright, J. (1959) Dermatologica 119, 105.

KoOIJ, R. and PePl.ER, W. J. (1961) Dermatologica 122, 360.

Mitsuda, K. (1919, 1953) Japanese J. Derm. Uro. 19, 967. Reprinted in English, Int. Journ. Lep. 21, 347.

Paras, E. M. (1943) Int. Journ. Lep. 11, 15.

Rabello, J., Thiers-Pinto, J. and Vil.lela, G. (1938) Int. Journ. Lep. 6, 462.

Shelley, W. B. and Huri.ey, H. J. (1960) J. Investigative Dermatol. 34, 107.

Sones, M., Israel, H. L., Krain, R. and Befrman, H. (1955) J. Investigative Dermatol. 24, 353. 